\title{
MEDIA APLIKASI BERBASIS AUGMENTED REALITY "COVID CARE" SEBAGAI BENTUK CORONA VIRUS PREVENTIVE ACTION (CVPA) BAGI PT UNITED TRACTORS
}

\author{
Agung Budi Prasetyo ${ }^{1}$, Muhammad Kahfi Rizki Pratama ${ }^{2}$ \\ ${ }^{1,2}$ Politeknik Negeri Media Kreatif, Jakarta.
}

\begin{tabular}{|c|}
\hline INFORMASI ARTIKEL \\
\hline $\begin{array}{l}\text { Sejarah Artikel: } \\
\text { Diterima Redaksi: } 3 \text { Maret } 2020 \\
\text { Revisi Akhir: } 15 \text { Juni } 2020 \\
\text { Diterbitkan Online: } 15 \text { Juli } 2020\end{array}$ \\
\hline KATA KUNCI \\
\hline $\begin{array}{l}\text { Coronavirus, COVID 19, Augmented Reality, } \\
\text { United Tractors, Media Aplikasi }\end{array}$ \\
\hline KORESPONDENSI \\
\hline $\begin{array}{l}\text { Email a: mkahfirizkipratama1@gmail.com } \\
\text { E-mail b: agung@polimedia.ac.id }\end{array}$ \\
\hline
\end{tabular}

\section{A B S T R A C T}

\section{PENDAHULUAN}

Coronavirus merupakan suatu golongan virus yang bisa menyebabkan penyakit pada binatang atau manusia. Sebagian tipe coronavirus dikenal menyebabkan infeksi saluran napas pada manusia mulai dari batuk pilek sampai yang lebih kompleks seperti Middle East Respiratory Syndrome (MERS) dan Severe Acute Respiratory Syndrome. Coronavirus jenis baru ini dikenal dengan istilah COVID-19 penyakit ini memiliki tingkat kematian yang terbilang rendah dari jenis Coronavirus lain nya yatu hanya berada di kisaran $2 \%$ tetapi virus baru ini memiliki tingkat penyebaran yang lebih cepat dari pada jenis virus lainnya. Indonesia sendiri tingkat penyebaran Covid-19 terbilang cukup cepat dan luas, dalam 4 bulan terakhir sejak di umumkan per tanggal 2 Maret 2020 sampai hari ini ditanggal 29 Juli 2020 menurut data dari kementrian kesehatan republik Indonesia dalam websitenya tercatat sudah mencapai total 104 ribu kasus pasien positif Covid-19 pasien sembuh sebanyak 62.138 dan pasien meninggal sebanyak 4.975 ribu kasus \& penderita penyakit Covid di Indonesia sudah sembuh dan tingkat kematian di Indonesia sendiri merupakan tingkat kematian yang bisa dibilang tinggi dan sudah mengalami penurunan sedikit demi sedikit dengan persentase $5,88 \%$ dari tingkat persentase tersebut juga berdampak terhadap smua sektor yang ada di Indonesia seperti ekonomi, bisnisperdagangan, dan lain sebagainya. Berbagai macam perusahaan dan proyek menjadi terhambat akibat pandemi ini. Berdasarkan sumber dalam website pemerintah DKI Jakarta di tingkat penyebaran nya terbilang banyak, terkonfirmasi pasien postif sejumlah 20,572 ribu kasus dan pasien sembuh sebannyak 12.614 dan meninggal sebanyak 798 orang. PT United Tractors Tbk adalah sebuah perusahaan perseroan yang bergerak sebagai distributor tunggal alat berat Komatsu di Indonesia. PT United Tractors Tbk memiliki lima unit usaha yaitu mesin konstruksi, kontraktor penambangan, pertambangan, konstruksi dan energy. Dalam upaya pencegahan itu sendiri UT sudah melakukan berbagai macam upaya dalam menangani pandemik yang menyebar dengan cepat ini seperti pada bulan februari pada saat pandemi ini menjadi wabah di Tiongkok pihak UT sudah melakukan yang namanya pojok sehat yaitu program sharing tentang bahaya dan pencegahan Covid-19. Terkait hal hal tersebut penulis menjadikan penyuluhan dan pencegahan tersebut dalam bentuk yang dapat di gunakan semua kalangan terutama karyawan dan pekerja UT dengan adanya aplikasi edukasi interaktif berbasis Augmented Reality. Augmented Reality (AR) sendiri bisa diartikan sebagai salah satu bentuk teknologi yang bias membuat dan menjadikan benda maya dua dimensi atau tiga dimensi ke dalam sebuah lingkungan yang 
nyata dan menggabungkan nya serta kemudian memunculkannya atau memproyeksikannya secara real time. AR bisa diaplikasikan untuk menolong memvisualisasikan konsep imajiner untuk pemahaman dan struktur suatu contoh obyek.. Media edukasi seperti AR dan media kesehatan seperti ini akan membuat penggunannya lebih mudah untuk memahami tentang informasi di bidang kesehatan seperti ini. Terutama dalam penyakit Covid19 ini. Dan juga menjadikan para karyawan dan pekerja dapat teredukasi secara mandiri serta menjadikan management kesehatan UT dapat berkembang ke media yang baru dan bersifat interaktif dan juga terorganisir.

\section{TINJAUAN PUSTAKA}

\subsection{COVID-19}

Corona Virus Deasese 19 (COVID-19) adalah sebuah jenis virus yang menyerang sistem saluran pernapasan yang diakibatkan oleh Corona Virus, Corona virus yang sedang mewabah di dunia sekarang inin merupakan salah satu jenis virus yang beru dan berbeda dengan virus sebelumnya yaitu MERS dan SARS. COVID-19 merupakan penyakit menular yang disebabkan oleh tipe virus yang baru yaitu coronavirus yang baru baru ini ditemukan. Virus baru dan penyakit yang diakibatkan oleh virus ini tidak dapat diidentifikasi sebelumnya, awalnya virus ini mewabah di Wuhan, Tiongkok, bulan Desember 2019. COVID19 ini sekarang menjadi sebuah pandemi yang terjadi di banyak negara di seluruh duniaMenurut pengertian yang dikeluarkan oleh WHO, COVID-19 adalah penyakit menular yang disebabkan oleh jenis coronavirus yang baru ditemukan. Sampai saat ini vaksin untuk COVID-19 belum ditemukan, dan untuk Corona Virus ini sendiri sebenarnya tidak mematikan tetapi ia memiliki tingkat penyebaran yang sangat cepat dan masih sulit untuk di deteksi karena jenis ini merupakan jenis virus yang baru. Corona jenis baru ini berbeda dengan pendahulunya seperti SARS dan MERS. Corona Virus yang saat ini menyebar di banyak negara ini belum ada obatnya, oleh karena itu sekiranya ada gejala biasanya akan di pantau dan di periksa. Sementara itu pemerintah dan pihak medis akan memberikan tata laksana pengobatan untuk gejala-gejalanya. Perlu di ingat bahwa belum ada vaksin untuk terkini ini. Vaksin yang ada di Indonesia pada

\subsubsection{Penyebaran Covid-19}

Dalam penyebarannya virus Covid-19 ini memiliki tingkat penyebaran yang terbilang cepat, karena jika seorang yang sudah terpapar virus ini akan menunjukan gejala yang hampir mirip dengan jenis penyakit flu atau demam. Namun dalam kasus Covid ini memiliki gejala-gejala seperti penjelasan menurut Pradipta Kusuma, post doktoral LBM Eijikman menjelaskan bahwa virus corona bisa berubah sehingga dapat menjadikan nya dalam karakter karakter virus corona yang baru dan mempunyai "ciri" asam amino tertentu. Simpelnya, ragam virus yang lazimdi dunia itu (S, G, atau V) seperti pengelompokan kelas atau pengelompokan warna."Jadi pengelompokkan ditandai oleh perubahan unik pada asam amino yang ada di RNA virus,".tipe virus Corona yang ada di Indonesia tidak memiliki mutasi seperti pada kelompok S, V, G dalam arti tipe jenis virus Corona yang ada di Indonesia memiliki penanda lain. Dikarena kan Virus ini terbentuk dan memiliki ciri yang terbentuk dari zat asam amino, maka cara untuk mencegahnya yang saat ini bisa mengurangi proses penyebarannya ialah dengan mencuci tangan dan menjaga diri dari kerumunan.

\subsubsection{Pencegahan Covid-19}

Dalam upaya pencegahan COVID-19 sendiri banyak negara sudah menerapkan beberapa peraturan-peraturan terkait pencegahan COVID-19. Seperti hal nya pemerintah Indonesia melalui kementrian kesehatan dalam pedoman kemenkes bab 4 "Pencegahan dan Pengendalian Infeksi" menyatakan tindakan pencegahan dann mitigasi merupakan kunci penerapan di masyarakat dengan melakukan hal hal berikut ini seperti:

1. Melakukan kebersihan mencuci tangan menggunakan sabun atau hand sanitizer jika terlihat kotor ataupun ketika setelah bersentuhan dengan benda yang ada diluar.

2. Menghindari menyentuh bagian mata, hidung dan mulut,

3. Menerapkan etika batuk atau bersin dengan menutup hidung dan mulut dengan lengan atas bagian dalam atau dengan menggunakan sapu tangan/ tisu. Lalu jika sudah membuang tisu kedalam tempat sampah

4. Memakai masker medis jika mempunyai pertanda gangguan pernapasan dan melakukan mencuci tangan setelah membuang masker, namun sebelumnya gunting masker bekas pakai agar tidak digunakan orang lain

5. Menjaga jarak minimal 1 meter dengan orang yang mengalami gejala gangguan pernapasan.

Pencegahan Corona Virus ini sendiri sangat mudah untuk dilakukan oleh siapa saja dan dimana saja, seperti hal nya langkah pemerintah yang sudah menerbitkan aturan untuk PSBB atau Pembatasan Sosial Bersekala Besar dalam Peraturan Pemerintah PP No 21-2020 yang dimuat dalam pasal 1 yang berbunyi bahwa yang dimaksud dengan PSBB adalah pembatasan kegiatan tertentu penduduk dalam suatu wilayah yang diduga terinfeksi COVID-19 sedemkian rupa untuk mencegah kemungkinan penyebaran COVID-19.

\subsection{Augmented Reality}

Augmented Reality (AR) atau realitas tertambah merupakan sebuah teknologi yang dimana membuat dunia maya dengan dunia realita menyatu menjadi satu. Didalam penggunaannya para pengguna AR bisa merasakan meliihat objek virtual secara real time, yang dimana objek virtual tersebut tidak ada di dunia nyata dan bisa dimunculkan oleh $A R$ itu sendiri. Menurut Ronald T. Azuma (1997) $A R$ merupakan variasi dari Virtual Environments (VE), atau yang lebih dikenal dengan istilah Virtual Reality $(V R)$. Teknologi $V R$ membuat pengguna tergabung dalam sebuah lingkungan virtual secara keseluruhan dalam penggunaannya teknologi $V R$ berbeda jauh dengan teknologi $A R$. Teknologi $A R$ memungkinkan penggunannya melihat keadaan yang tidak nyata dengan dimasukannnya objek maya di dalamnya, jadi para pengguna dapat melihat objek maya yang tidak dapat dilihat di dunia nyata didalam Augmented Reality. Dalam penggunaan nya $A R$ sendiri mempunyai berbagai macam cara kerja yang berbeda dan masing-masing cara system kerja $A R$ itu sendiri membutuhkan komponen yang berbeda juga, seperti jenis-jenis $A R$ berikut ini

\subsubsection{Marker Augmented Reality}

Salah satu jenis marker Augmented Reality yaitu dengan system marker based atau menggunakan marker sebagai alat untuk 
mendeteksi tanda atau pola yang sudah di identifikasi dengan gadget dan juga dengan program yang sudah ada. Cara menggunakannnya yaitu dengan mengescan marker yang telah tersedia lalu $A R$ akan otomatis mendeteksi dan memunculkan apa yang telah di scan dan objek akan muncul di gadget anda.

\subsubsection{Markerless Augmented Reality}

Selain dengan menggunakan marker sebagai alat untuk mendeteksi objek, Augmented Reality sendir juga bias menerapkan nya dengan konsep markerless, lalu apa itu markerless. Markerless sendiri adalah konsep penggunaan scan terhadap objek di $A R$ yang dimana tidak menggunakan benda, biasanya markerless menggunakan fitur pendeteksian lokasi pada smartphone dan biasanya diimplementasikan secara luas seperti digunakan pada GPS, kompas digital, mengukur kecepatan dan juga games. $A R$ akan mendeteksi objek yang sudah dikalibrasikan di software dan akan memunculkan nya di gadget.

\subsubsection{Projection Based Augmented Reality}

Projection Based Augmented Reality sendiri ialah penggunaan $A R$ dengan menggunakan cahaya sebagai penghantar ke media yang akan di scan. Teknologi ini memungkinkan adanya proses interaksi manusia dengan mengirimkan cahaya ke permukaan asli. Proses scan objek pada Projection Based Augmented Reality ini biasanya menggukanan media seperti proyektor untuk memproyeksikan hologram ke dalam objek asli melalui cahaya.

\subsection{Multimedia Interaktif}

\subsubsection{Pengertian Multimedia Interaktif}

Multimedia interaktif adalah sebuah proses penggabungan elemen multimedia yang berupa teks, grafik, video, animasi, dan juga suara kedalam suatu objek atau media yang bertujuan untuk menyampaikan sebuah pesan atau informasi menjadi lebih menarik dan juga agar penyampaiannya menjadi lebih efesien dan mudah. Menurut penjelasan Hofstetter (seperti dikutip Benardo, 2011) Multimedia interaktif adalah pemanfaatan komputer untuk membuat dan menggabungkan teks, grafik, audio, gambar bergerak (video dan animasi) dengan menggabungkan link dan tool yang memungkinkan pemakai melakukan navigasi, berintraksi, berkreasi dan berkomunikasi

\subsubsection{Jenis Multimedia Interaktif}

A. Multimedia interaktif tidak hanya sebgai satu media saja tapi memiliki jenis karakteristiknya sendiri, seperti berikut ini:

1. Multimedia interaktif online merupakan media interaktif yang menggunakan metode penyampaian melewati jaringan. contohnya seperti web, Facebook, dan lainnya. Variasi media ini termasuk media lini atas, yang target jangkauan nya luas, dan meliputi masyarakat luas.

2. Multimedia interaktif offline yaitu media interaktif yang menggunakan sistem penyampainnya tidak melalui jalur yang speerti media interaktif online . Contohnya seperti CD interaktif : Company Profile, Media Pelajaran. Media ini merupakan media lini bawah dikarenakan target penggunanya, tidak terlalu luas dan hanya meliputi masyarakat pada kalangan tertentu saja Fungsi Multimedia Interaktif

\subsubsection{Fungsi Multimedia Interaktif}

Dalam penggunaannya multimedia interaktif sendiri dapat difungsikan dalam bidang bidang seperti ini:

1. Fungsi komunikasi antar pengguna contohnya seperti sosial media

2. Fungsi komunikasi antar bisnis dari penjual dan pembeli contohnya seperti $e$-commerce

3. Fungsi komunikasi dari pemerintah ke masyrakat contohnya seoerti website atau media media pemerintah

4. Sebagai sarana hiburan atau games

5. Sebagai sarana kebudayaan contohnya seperti aplikasi atau website museum atau galeri

6. Sebagai $E$ learing yang menjadikan media pembelajaaran yang interaktif

\section{KONSEP PERANCANGAN}

Dalam pembuatan tugas akhir ini, penulis akan membuat media aplikasi AR yang berdasarkan dari salah satu program kesehatan penanganan COVID 19 yang akan dilakukan oleh PT United Tractors yaitu program CVPA. Pada aplikasi ini akan berisis AR yang dimana akan memunculkan video berupa protokol kesehatan dan juga beberapa data penyebaran COVID 19 , dan juga data kesehatan dalam healthy monitoring untuk mengisi data kesehatan pada karyawan

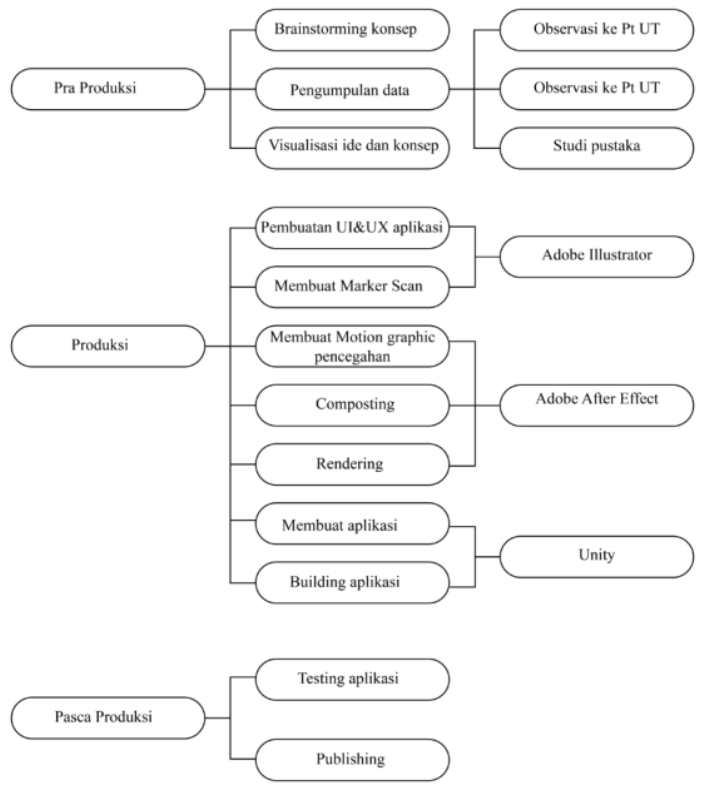

Dalam pembuatan aplikasi interaktif yang akan dibuat sebagai proses media edukasi kepada karyawan terhadap COVID-19 yaitu dengan aplikasi Covidcare dibagi menjadi 3 tahapan, yang 
pertama ialah tahapan pra produksi, kedua ialah produksi dan yang ketiga yaitu pasca produksi

\subsection{Use case}

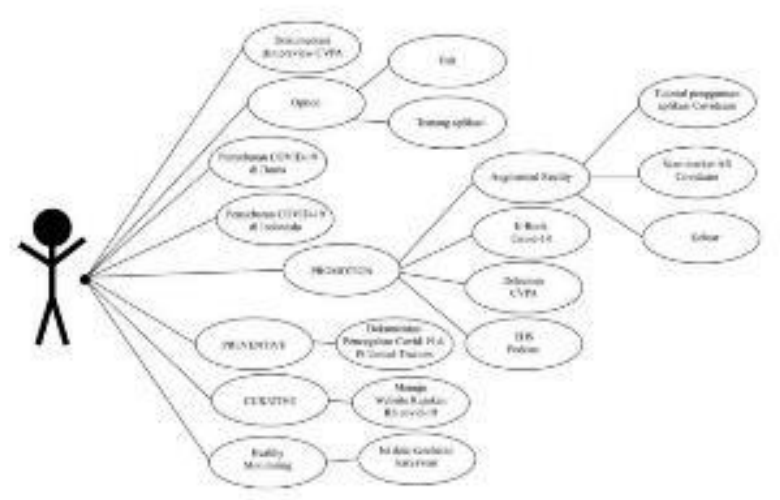

Use Case diatas merupakan rangkaian/uraian pengguna yang saling terkait dan membentuk sistem secara teratur yang diawasi oleh sebuah aktor. Use case digunakan untuk membentuk apa yang dilakukan oleh pengguna yang direalisasikan oleh sebuah system

\subsection{Activity Diagram}

\subsubsection{Activity Diagram Preview Dokumentasi\&CVPA}

Activity Diagram ini menggambarkan aktivitas ketika user membuka aplikasi lalu system akan merespon untuk menunjukan halaman utama atau main menu dan user bisa melihat dan berinteraksi dengan menggeser konten utama yaitu preview dokumentasi CVPA dan system akan menunjukan beberapa isi dokumentasi CVPA

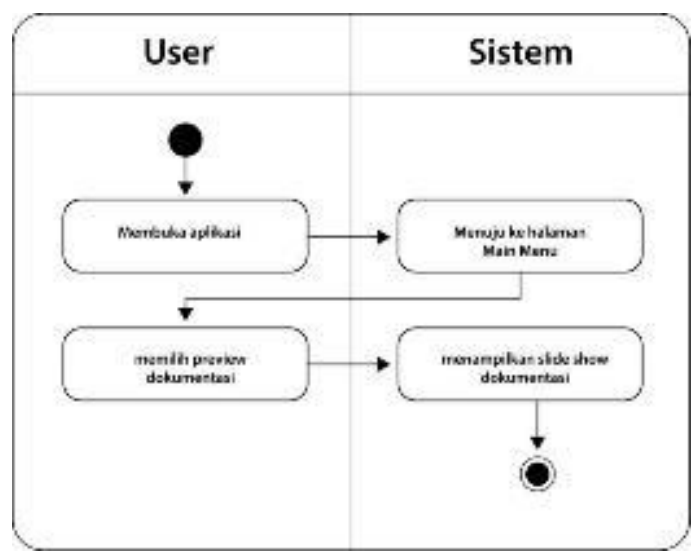

\subsubsection{Activity Diagram Info Aplikasi}

Activity Diagram ini menggambarkan aktivitas ketika user menjalankan aplikasi lalu sistem otomatis menuju main menu dan setelah itu ketika user ingin membuka menu info aplikasi dan sistem menampilkan info aplikasi

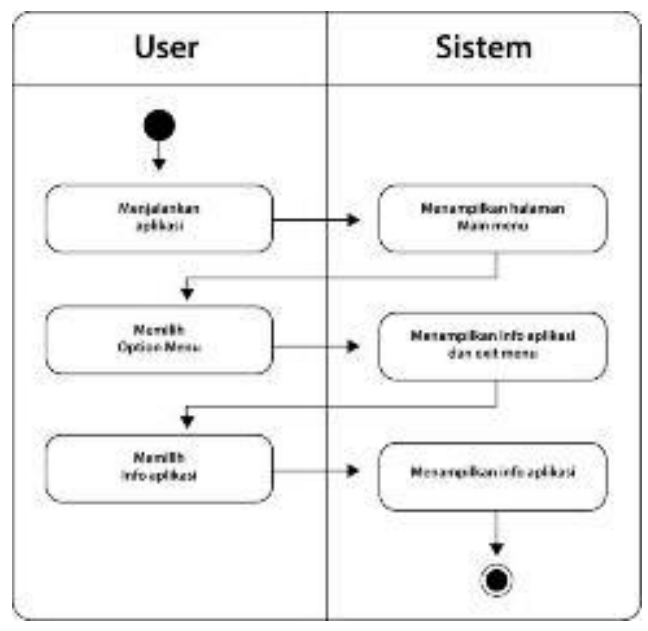

\subsubsection{Activity Diagram Penyebaran Covid-19 di Dunia}

Activity Diagram ini menggambarkan aktivitas ketika user membuka aplikasi lalu memilih tombol penyebaran Covid $19 \mathrm{di}$ dunia lalu otomatis akan di tujukan ke halaman utama website penyebaran covid 19 di dunia

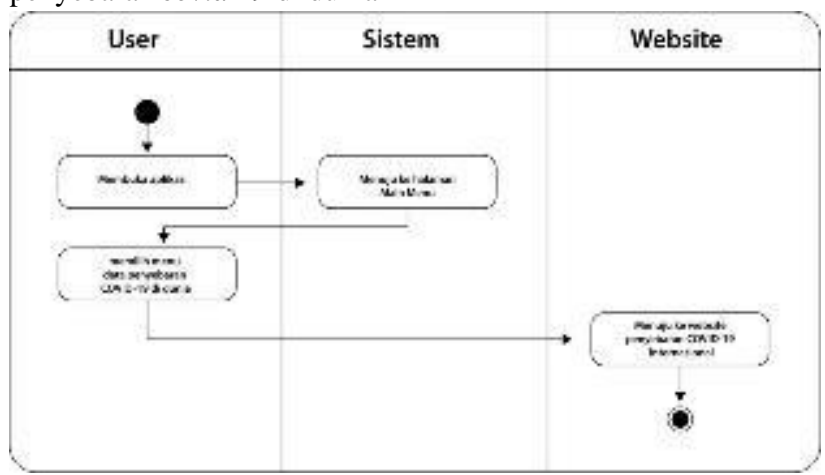

\subsubsection{Activity Diagram Penyebaran Covid-19 di Indonesia}

Activity Diagram ini menggambarkan aktivitas ketika user membuka aplikasi lalu memilih tombol penyebaran Covid 19 di Indonesia lalu otomatis akan di tujukan ke halaman utama website penyebaran covid 19 di Indonesia

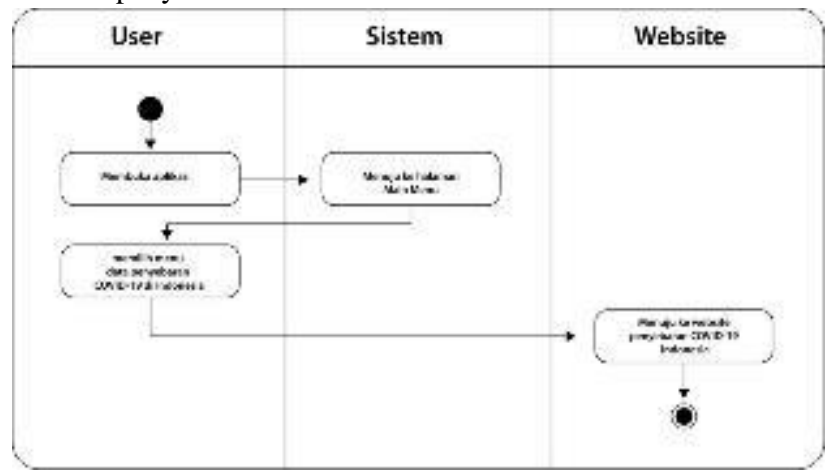

\subsubsection{Activity Diagram Penyebaran Covid-19 di DKI Jakarta}

Activity Diagram ini menggambarkan aktivitas ketika user membuka aplikasi lalu memilih tombol penyebaran Covid $19 \mathrm{di}$ DKI Jakarta lalu otomatis akan di tujukan ke halaman utama website penyebaran covid 19 di DKI Jakarta 


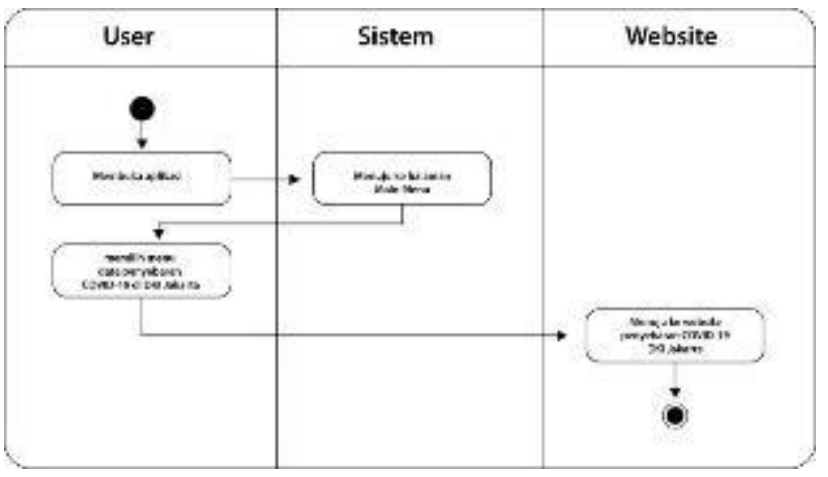

\subsubsection{Activity Diagram AR Scene}

Activity Diagram ini menggambarkan aktivitas ketika user akan menekan tombol promotion lalu sistem akan menampilkan halaman promotion dan user bisa memilih konten AR lalu sistem akan otomatis menampilkan isi tutorial cara penggunaan AR dan setelah itu sistem akan langsung menampilkan isi AR Camera, lalu user bisa mengarahkan ke marker yang sudah tersedia dan objek video akan dimunculkan oleh sistem.

\section{Promotion Scan AR}

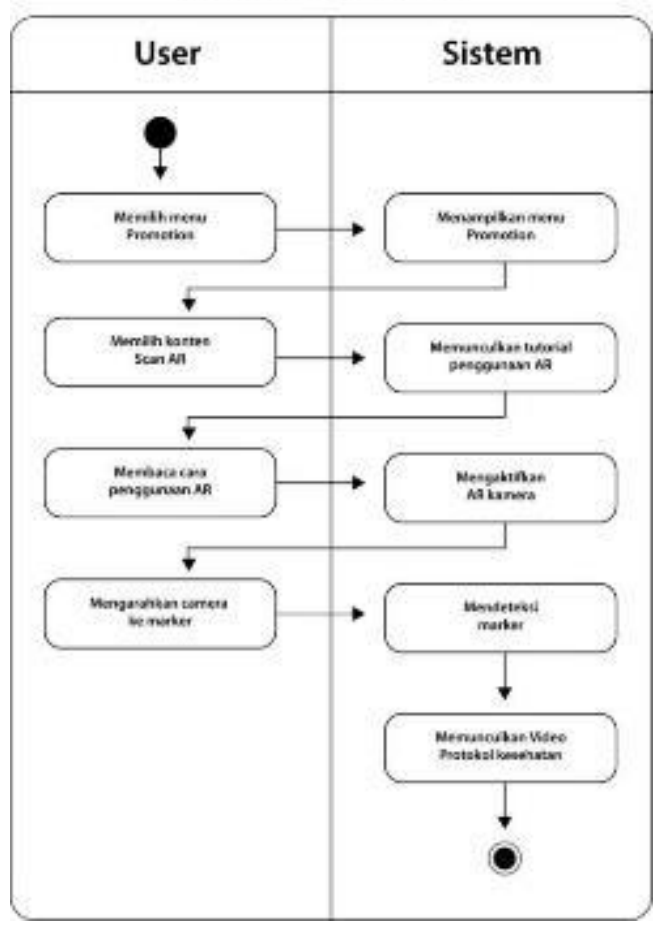

\subsubsection{Activity Diagram E-Book Covid-19}

Activity Diagram ini menggambarkan aktivitas ketika user memilih menu promotion lalu sistem menampilkan konten didalam nya dan user bisa memilh konten $E$ book, lalu sistem menampilkan infografis-infografis yang bisa user baca.

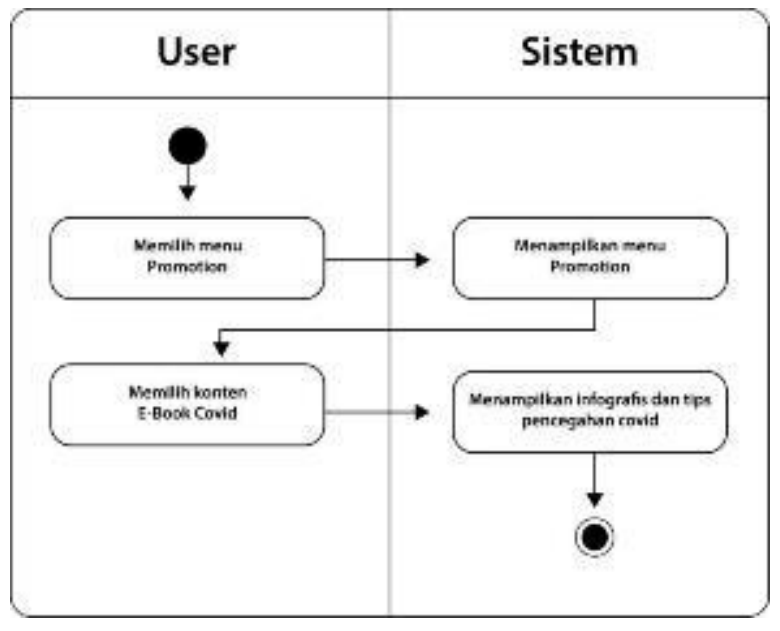

\subsubsection{Activity Diagram Dokumentasi CVPA}

Activity Diagram ini menggambarkan aktivitas ketika user membuka konten dokumen CVPA, lalu sistem akan merujuk ke website dimana user bisa mengkases data terkait dokumen CVPA tersebut

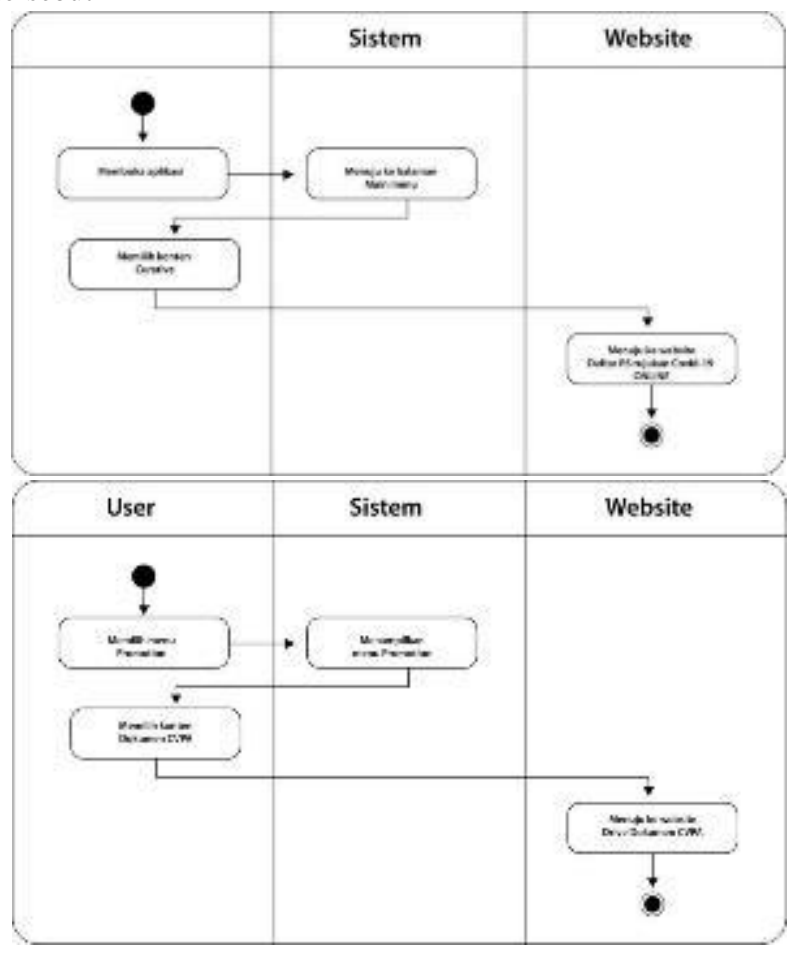

\subsubsection{Activity Diagram EHS Channel}

Activity Diagram ini menggambarkan aktivitas ketika user membuka konten EHS Channel, lalu sistem akan merujuk ke Youtube EHS dimana terdapat video terkait kegiatan yang dibuat oleh PT United Tractors khususnya department EHS 


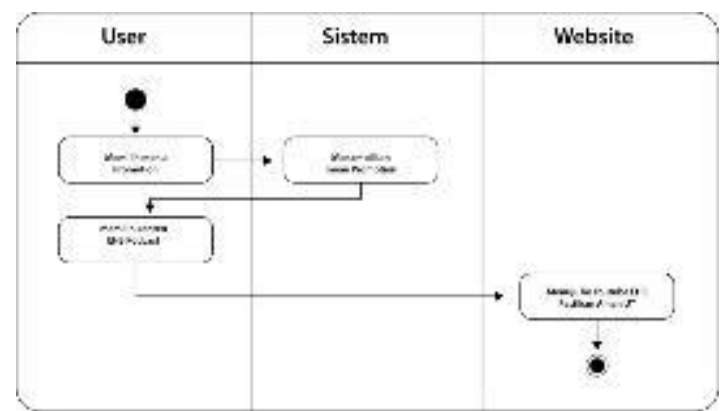

3.2.10. Activity Diagram Preventive

Activity Diagram ini menggambarkan aktivitas ketika user memilih konten preventive dan sistem menampilkan proses kegiatan physical distancing yang diterapkan oleh PT United Tractors

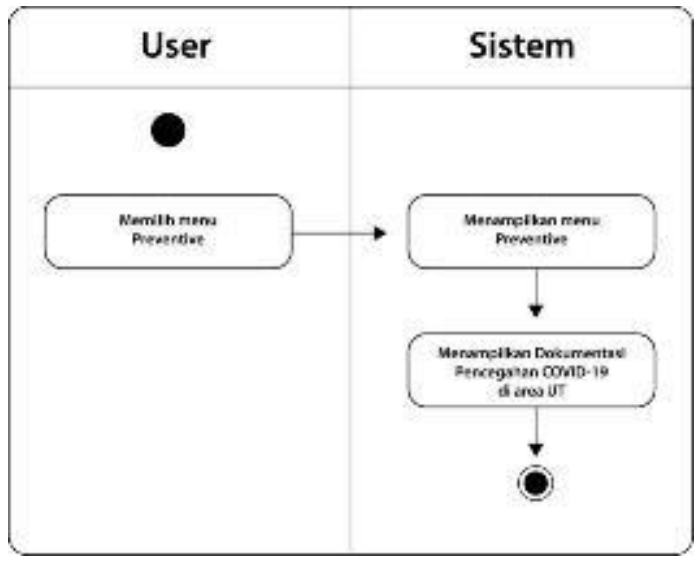

\subsubsection{Activity Diagram Curative}

Activity Diagram ini menggambarkan aktivitas ketika user menekan tombol curative maka sistem akan memunculkan website list rumah sakit yang bisa di datangi ketika karyawan merasa sakit

\subsubsection{Activity Diagram Healthy Monitoring}

Activity Diagram ini menggambarkan aktivitas ketika user menekan tombol healthy monitoring maka sistem akan merujuk ke website dimana karyawan bisa langsung mengisi form data kesehatan secara rutin.

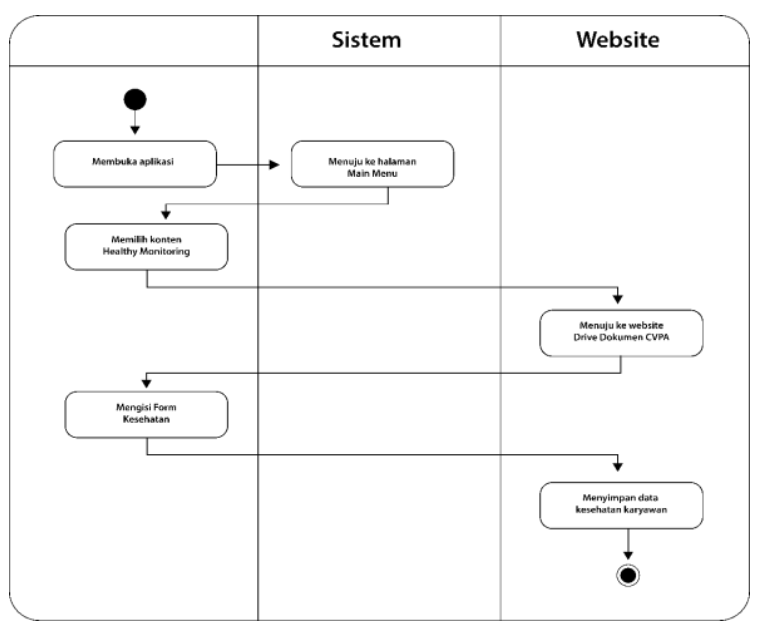

\subsection{Class Diagram}

Class diagram mendiskripsikan jenis-jenis objek dalam sistem dan berbagai macam hubungan statis yang terjadi. Selain itu, class diagram juga menunjukan property atau atribut dan operasi atau sebuah fungsi dari sebuah class dan batasan yang terdapat dalam hubunggan dengan objek. Class diagram merupakan alat yang tergolong baik dalam perancangan perangkat lunak.

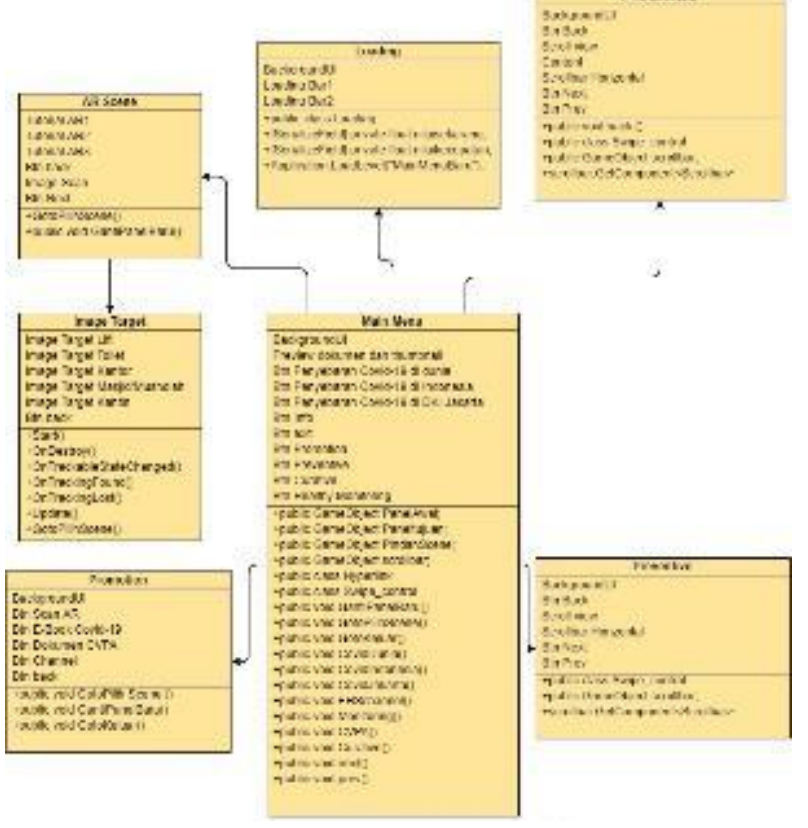




\section{HASIL DAN PEMBAHASAN}

\subsection{Tabel}

Berikut merupakan tabel ukuran Aset yang digunakan dalam aplikasi

Tabel 1. Penggunaan Aset

\begin{tabular}{|l|l|}
\hline \multicolumn{1}{|c|}{ Aset } & \multicolumn{1}{c|}{ Ukuran } \\
\hline Background & $1920 \times 1080 \mathrm{px}$ \\
\hline Button kembali & $173,15 \times 86,75 \mathrm{px}$ \\
\hline Button info aplikasi dan exit & $100,52 \times 100,52 \mathrm{Px}$ \\
\hline Button Penyebaran Covid Dunia & $317,62 \times 317,62 \mathrm{Px}$ \\
\hline Button Penyebaran Covid Indonesia & $317,62 \times 317,62 \mathrm{Px}$ \\
\hline Button Penyebaran Covid Jakarta & $317,62 \times 317,62 \mathrm{Px}$ \\
\hline Button Promotion & $173,15 \times 173,15 \mathrm{Px}$ \\
\hline Button Preventive & $173,15 \times 173,15 \mathrm{Px}$ \\
\hline Button Curative & $173,15 \times 173,15 \mathrm{Px}$ \\
\hline Button Healthy monitor & $173,15 \times 173,15 \mathrm{Px}$ \\
\hline Button Scan AR & $831,15 \times 229,72 \mathrm{Px}$ \\
\hline Button E Book Covid & $831,15 \times 229,72 \mathrm{Px}$ \\
\hline Button Dokumen CVPA & $831,15 \times 229,72 \mathrm{Px}$ \\
\hline Button EHS Channel & $831,15 \times 229,72 \mathrm{Px}$ \\
\hline Button Next dan Previous & $132,58 \times 32,88 \mathrm{Px}$ \\
\hline
\end{tabular}

Berikut merupakan asset dan background yang digunakan dalam pembuatan aplikasi.

Tabel 2. Aset dan Background

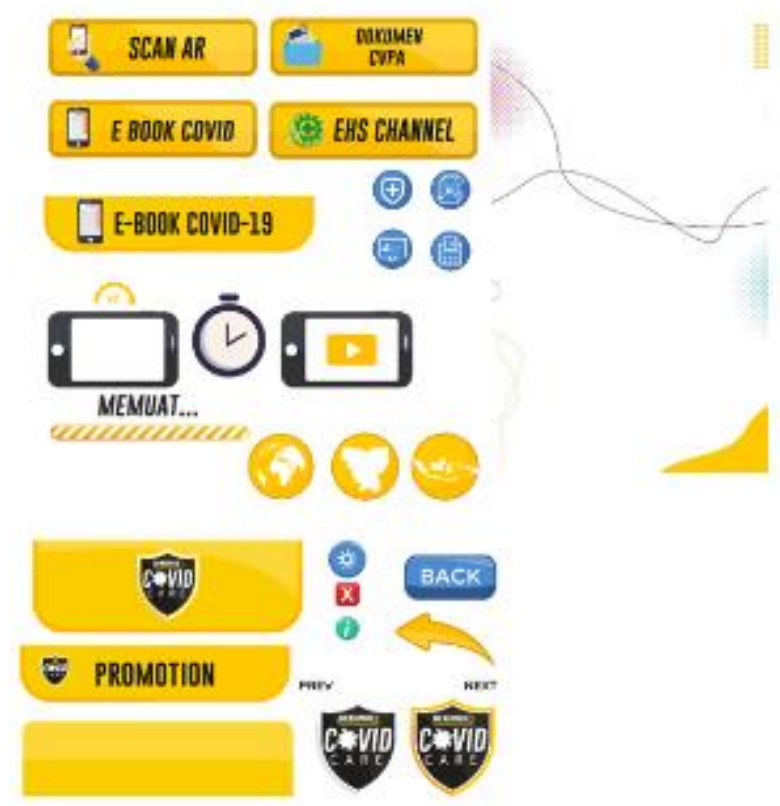

Berikut merupakan beberapa jenis tipe perangkat yang di uji coba dalam pembuatan aplikasi ini

Tabel 3. Jenis perangkat

Muhammad Kahfi Rizki Pratama

\begin{tabular}{|c|c|c|c|c|c|c|}
\hline \multirow{2}{*}{ 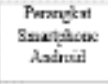 } & \multicolumn{6}{|c|}{ Sperificud Pronder } \\
\hline & Prosesom & $\mathrm{BNM}$ & $\begin{array}{l}\text { Resthe } \\
\text { Kaners }\end{array}$ & $\begin{array}{l}\text { tores } \\
\text { Lxyer }\end{array}$ & OE ADISA & Strawei \\
\hline Penarglot 1 & Ota-est $1.4 \mathrm{CH} z$ & 308 & $13 \mathrm{Mg}$ & $\begin{array}{c}1036 \times 1920 \\
\mathbf{P x}\end{array}$ & $\begin{array}{c}\text { Antrid } \\
7.1 \text { Nosed }\end{array}$ & $32 \mathrm{cs}$ \\
\hline Ferundest 2 & 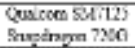 & 96 & BSD & 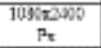 & Ásions 10 & $123 \mathrm{GE}$ \\
\hline Paushix 3 & 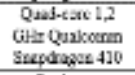 & $1,2 \mathrm{~GB}$ & 139 & $720 \mathrm{x} .210 \mathrm{Px}$ & Substail 6.01 & DGGB \\
\hline Paushat.4 & $\begin{array}{c}\text { Quless- } \\
\text { Snapdapose aj3 }\end{array}$ & $4 G B$ & 133! & 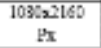 & $\begin{array}{l}\text { funlicid } \\
\text { S(Pst) }\end{array}$ & GAGB \\
\hline
\end{tabular}

Berikut merupakan hasil pengujian di beberapa jenis perangkat

Tabel 4. Hasil pengujian

\begin{tabular}{|c|c|c|c|c|}
\hline \multirow{2}{*}{ Proun Qperawi Apilase } & \multicolumn{4}{|c|}{ 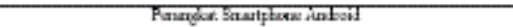 } \\
\hline & Fatale & Fatsh & Paushas 3 & Fatughel \\
\hline Lasting xpibu & Baplangrax & Thejlalusex & Fifjon bers & Barjen lnses \\
\hline 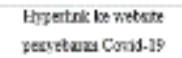 & Bxyly $1 \pi x$ & Bercelas larex & Begalre incer & Bardan Inex \\
\hline 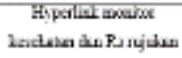 & Bxdaluse & Berdater & 3edum & Badaluaz \\
\hline 'ंtan $A ?$ & Baplaniuter & Bajlaninew & Befjunhat & Bajlatane \\
\hline TSetsers morlines & 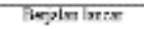 & Thepla mex & Tiejon berst & Fisplenturse \\
\hline E-3oskCout1-19 & Brrdyaluex & Bradzalarex & Berdalu kencu & Bardanlater \\
\hline 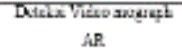 & Bxylature & 3stalust & उejumLx & Budaluse \\
\hline 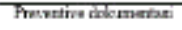 & Beplalatix & Beglatartax & Fefpln brax & Baphlaluse \\
\hline 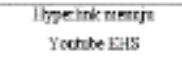 & incian intre & 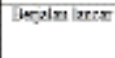 & Iensin inctr & bapplen intse \\
\hline 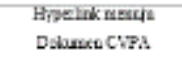 & Brydaluex & Berdaleser & Berdalewer & Bardalase \\
\hline Gatasallex & 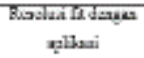 & 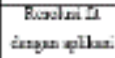 & 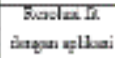 & 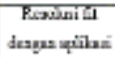 \\
\hline
\end{tabular}

\subsection{Gambar}

\subsubsection{Splash Screen}

Berikut merupakan tampilan layar dari splash screen ketika aplikasi di buka

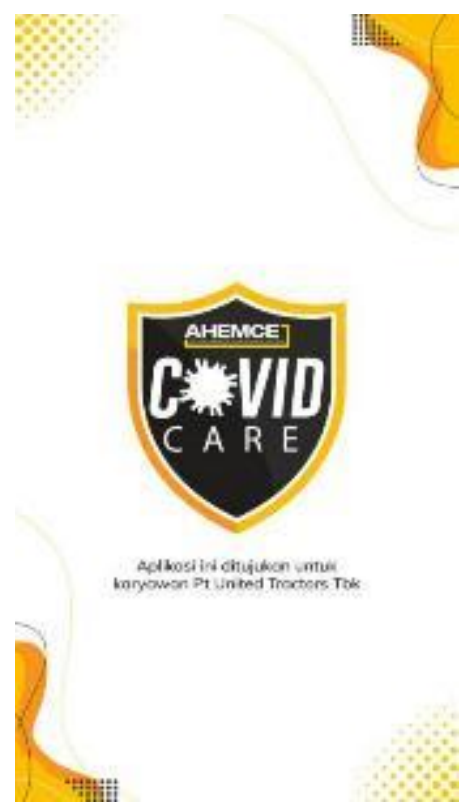


Gambar 1. Splash Screen

\subsubsection{Loading Screen}

Berikut merupakan tampilan layar dari Loading screen ketika aplikasi akan menuju main menu

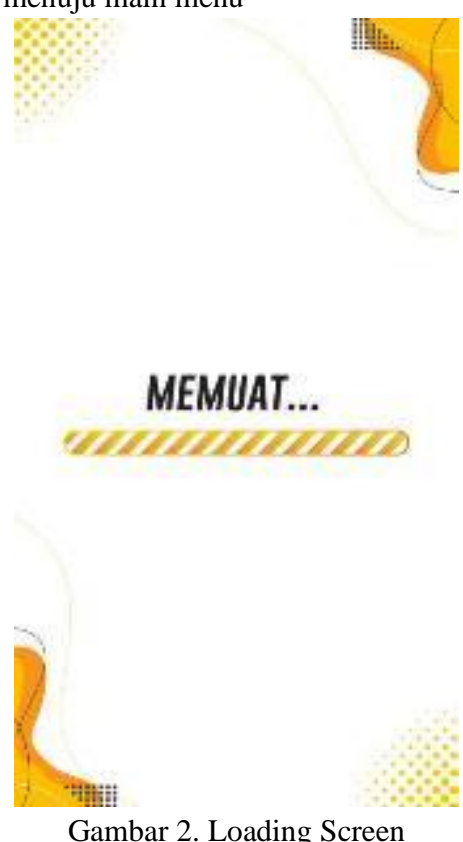

\subsubsection{Main menu Screen}

Halaman Main Menu adalah tampilan yang berisi inti dari aplikasi "Covidcare" itu sendiri dan didalam nya tersedia berbagai macam konten yang bisa pengguna gunakan untuk mencegah, memantau data kesehatan dan mendapatkan informasi terkait COVID-19
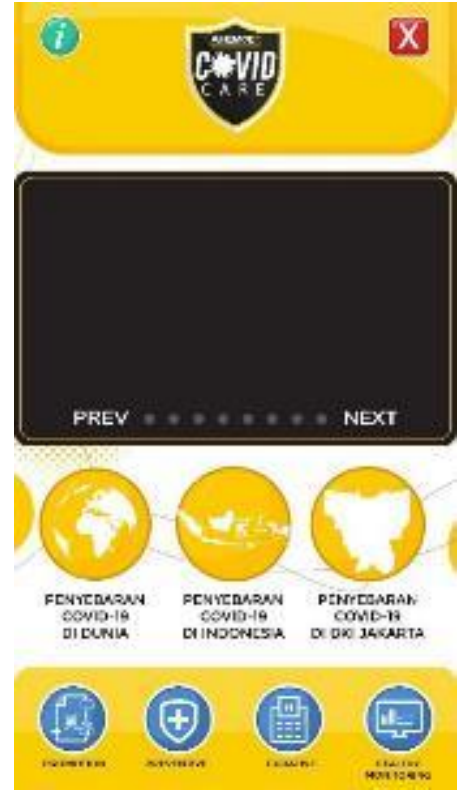

Gambar 3. Main menu Screen

\subsubsection{Promotion Screen}

Berikut merupakan tampilan layar dari Promotion screen dimana berisi konten utama yaitu terdapat AR scan, E book covid, Dokumen CVPA, dan juga EHS channel

\section{PROMOTION}

SCAN AR

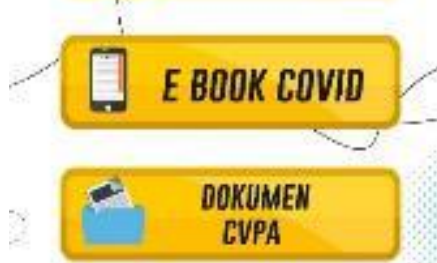

\section{S) EHS CHANNEL}

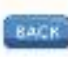

Gambar 4. Splash Screen

\subsubsection{AR Screen}

Berikut merupakan tampilan layar dari AR screen dimana sebelumnya terdapat cara menggunakan AR ini agar pengguna menjadi lebih mudah menggunakan nya
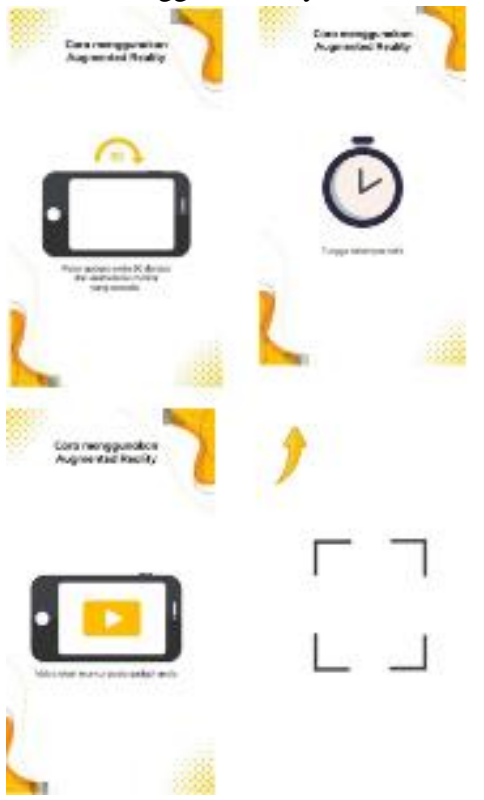

Gambar 5. Splash Screen

\subsubsection{Ebook Covid-19}

Berikut merupakan tampilan layar dari Ebook Covid-19 screen dimana berisi infografis terkait pencegahan covid-19 dan hal terkait informasi Covid-19 lainnya 


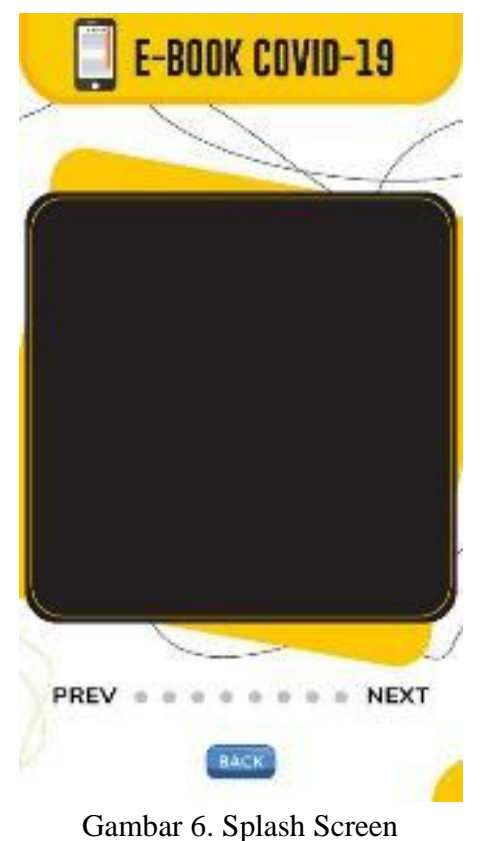

\subsubsection{Preventive Screem}

Berikut merupakan tampilan layar dari Preventive screen dimana berisi informasi dan dokumentasi tentang kegiatan Physical distancing di PT United Tractors

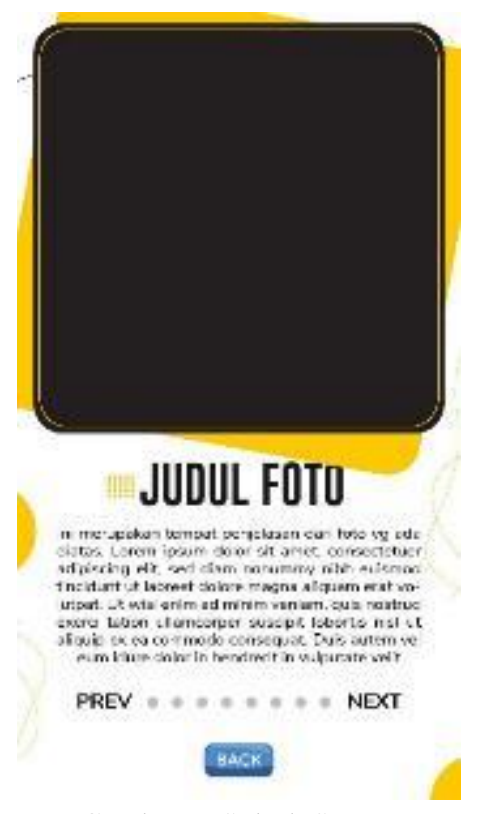

Gambar 7. Splash Screen

\section{KESIMPULAN DAN SARAN}

\subsection{Kesimpulan}

Kesimpulan karya tugas akhir terkait media aplikasi berbasis Augmented Reality "Covidcare" sebagai bentuk Corona Virus Preventive Action (CVPA) bagi PT United Tractors adalah sebuah solusi untuk pengaplikasian promosi kesehatan salah satunya di bidang penanganan COVID 19 yang sedang berjalan di PT UT dimana Corona virus yang sedang menyebar di seluruh wilayah terutama di DKI Jakarta dan khusus nya PT Ut sendiri. Adapun proses pembuatan aplikasi ini dimulai dari tahap rancangan konsep, ide dan mulai membuat motion graphic dan menyiapkan asset untuk di gabungkan dalam software Unity 3D dan hingga tahapan terakhiryaitu build aplikasi. Dan juga konten yang bisa di akses oleh karyawan yaitu berupa program penanganan COVID 19 yaitu program Promotion, Preventive, Curative dan juga Healthy monitoring dari media AR yang disajikan didalam aplikasi ini ialah berupa motion graphic protokol kesehatan yang bisa di akses karyawan melalui marker yang akan di letakan di beberapa tempat yang mengharuskan adanya protokol kesehatan tersebut.

\subsection{Saran}

Beberapa hal masih harus dikembangakn dari Aplikasi berbasis Augmented Reality ini diantaranya ialah sebagai berikut

1. Ukuran Aplikasi yang harus di kecilkan agar semua device dapat menggunakannya secara optimal

2. Dalam pengembangan aplikasi ini diharapkan dapat dibuat dengan versi markerless dimana dapat mendeteksi suhu tubuh melalu wajah karyawan

3. Website penyebaran covid di aplikasi ini di harapkan bisa terintegrasi langsung ke dalam aplikasi jadi tidak mengharuskan user mengakses dari browser device tapi bisa mengkases langsung di dalam aplikasi

4. Penambahan fitur update data untuk informasi dimana menampilkan data kasus Covid 19 di PT United Tractors

5. Pada aplikasi ini masih akan dikembangakn dalam fitur AR dimana akan menyesuaikan dengan protokol kesehatan yang terupdate

\section{DAFTAR PUSTAKA}

Daftar Pustaka ditulis mengikuti format IEEE style berikut:

\section{Referensi Cetak:}

Buku

T, Hoftstetter Fred, Multimedia Literacy. New York. 2011.

Rizky, R. Panduan Membuat Aplikasi Augmented Reality. Athana Studio

\section{$\underline{\text { Jurnal }}$}

Mustaqim, I, "PEMANFAATAN AUGMENTED REALITY SEBAGAI MEDIA PEMBELAJARAN"

Jurnal Pendidikan Teknologi dan Kejuruan, pp 13, 07/2016

\section{Peraturan Pemerintah}

Republik Indonesia. Pembatasan Sosial Bersekala Besar dalam Peraturan Pemerintah No 21-2020 yang dimuat dalam pasal 1

\section{Referensi Elektronik: \\ $\underline{\text { Buku }}$}

RI, Kementrian. Kesehatan.. (2020, March, 16). Pedoman Pencgehanan dan Pengendalian Coronavirus Diease. (3th 
edition). [On-line]. 19(52). Available:

https://covid19.kemkes.go.id/ [March 16, 2020].

\section{Web}

WHO. Coronavirus qna for public. Internet:

https://www.who.int/indonesia/news/novel-coronavirus/qa-forpublic, July. 29, 2020 [16. 08, 2020].

Gugus Tugas Percepatan Covid. Covid-19. Internet:

Covid.go.id: https://covid.go.id/, July. 29, 2020 [16. 08,

2020].

Burhan, Dr Erlina, M. S. pneumonia coronoa virus. Internet: www.yankes.kemenkes.go.id/read-pneumonia-corona-virus8488.html, February, 16, 2020 [16. 08,2020]

Covid DKI. Peta sebaran Corona Virus DKI Jakarta. Internet: https://corona.jakarta.go.id/id/peta-sebaran, July. 29, 2020 [16. 08, 2020].

\section{Sumber Lain:}

\section{Koran}

Sri Anindiati Nursastri. "Virus Corona Terus Bermutasi, Jenis Apa yang Ada di Indonesia?.” Kompas.com (24, 04, 2020), sains, pp 1

\section{BIODATA PENULIS}

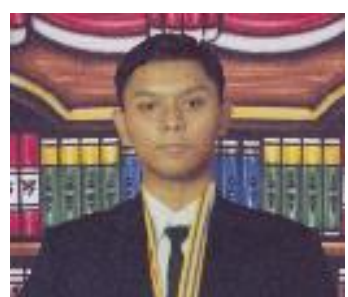

\section{Nama Mahasiswa:}

Muhammad Kahfi Rizki Pratama

Tempat Tanggal Lahir:

Jakarta, 02 April 1999

Email:

mkahfirizkipratama1@gmail.com 